Article

\title{
Sustainability of the Artisanal Fishery in Northern Chile: A Case Study of Caleta Pisagua
}

\author{
Carola Espinoza ${ }^{1,2}$, Víctor A. Gallardo ${ }^{1}$, Carlos Merino ${ }^{3}$, Pedro Pizarro ${ }^{3}$ \\ and Kwang-Ming Liu 1,4,5,*(D) \\ 1 Institute of Marine Affairs and Resource Management, National Taiwan Ocean University, 2, Pei-Ning Road, \\ Keelung 20224, Taiwan; carespin76@gmail.com (C.E.); vagallar@gmail.com (V.A.G.) \\ 2 Department of Oceanography, University of Concepción, Concepción 4030000, Chile \\ 3 Faculty of Natural Renewables Resources, Arturo Prat University, Iquique 2210000, Chile; \\ cmerino@unap.cl (C.M.); ppizarro@unap.cl (P.P.) \\ 4 George Chen Shark Research Center, National Taiwan Ocean University, 2, Pei-Ning Road, \\ Keelung 20224, Taiwan \\ 5 Center of Excellence for the Oceans, National Taiwan Ocean University, 2, Pei-Ning Road, \\ Keelung 20224, Taiwan \\ * Correspondence: kmliu@mail.ntou.edu.tw; Tel.: +886-2-2462-2192 (ext. 5018)
}

Received: 14 August 2020; Accepted: 3 September 2020; Published: 5 September 2020

check for updates

\begin{abstract}
The Humboldt Current, one of the most productive waters in the world, flows along the Chilean coast with high primary production level. However, living marine resources in these waters are declining due to overexploitation and other anthropogenic and environmental factors. It has been reported that deploying artificial reefs in coastal waters can improve the production of benthic resources. To ensure the sustainability of coastal fisheries in northern Chile this study aims to investigate fishermen's perceptions on deploying artificial reefs and propose future management measures using Caleta Pisagua as a case study. Interviews of artisanal fishermen regarding four aspects: fishermen profile, fishing activity, resources, and artificial reefs were conducted. Results showed that most fishermen favored the implementation of artificial reefs within the Areas of Management and Exploitation of Benthic Resources (AMERBs). In addition, deploying artificial reefs appears to be socio-economically necessary for the artisanal fishermen whose livelihood is being affected by the overexploitation of coastal fish and because hard substrates essential for benthic resources are in short supply within this administration area. It is recommended that criteria for the deployment of artificial reefs as well as specific management plans for main and secondary species should be developed.
\end{abstract}

Keywords: Humboldt Current; artisanal fishermen; interviews; hard substrate; literature review

\section{Introduction}

The Chilean fishery system comprises two sectors: 1.the industrial or large-scale fishery sector, and, 2. the artisanal or small-scale fishery sector. The former includes fishing vessels larger than $18 \mathrm{~m}$ in length that by law must operate outside the first five nautical miles from the coast. The latter includes fishing vessels of up to $15 \mathrm{~m}$ in length that operate within five nautical miles of coastal waters. The latter includes various types of artisanal fishermen and some of them exploit marine resources for which they have annual quotas approved by the Under-Secretariat for Fisheries and Aquaculture; and others (the minority) with licenses to act on different marine resources [1]. Artisanal fishermen are organized regionally (a scheme applied for most of the economic activities of Chile) and are entitled to operate only in the one particular region in which they have registered. In addition, benthic fishery regulations include quotas by region and species, which are allocated among the groups included in the Artisanal Fisheries Register [2]. 
An Area for the Management and Exploitation of Benthic Resources (AMERB) is an exclusive title for the exploitation of benthic resources (invertebrates and algae) granted to an artisanal fishermen union ("sindicato"). Fishermen are granted the right to manage the area rather independently, subject to certain monitoring by the fisheries authority. This right is assigned after the approval of a management plan based on conservation principles that is applied within previously delimited geographical spaces [3]. Currently, a total of 773 AMERBs encompassing 120,665 ha of seafloor bottom have been approved. Originally, AMERBs aimed at rationally exploiting the shellfish of the natural rocky substrate. It has partially proven to be a good option for increasing economic returns for some artisanal fishermen syndicates. This administrative decision was applied to the Chilean coast in support of the artisanal fishermen associations; however, since sites were approved without taking into account the geography and geomorphology of the area, many sites did not achieve the expected production goal due to the lack of sufficient hard substrate. This is one of the major problems and a solution is urgently needed since approximately $80 \%$ of Chilean benthic resources require rocky substratum.

Caleta Pisagua is a remote, historically valuable fishing village, in direct contact and dependent on the productivity of the Humboldt Current Large Marine Ecosystem. In the 1920s and 1930s, the fishing was oriented to the harvest of pelagic species in addition to shellfish such as sea urchin, large mussels, squat lobster, king crab, and the large snail "loco". The latter species was the driver that led to the creation of the AMERBs in 1990. In Caleta Pisagua, there were approximately 260 residents (2002 census) with the number increasing during summer seasons for the harvesting of shellfish. The village is currently deficient in infrastructure and basic services are generally marginal.

There are two groups of artisanal fishers in Caleta Pisagua: (1) the pelagic group, or coastal, or white fishing that comprises small boats and the use of traditional methods. The target species are black conger, Peruvian seabass, Pacific red sheepshead, and other benthic fish, and (2) the benthic group or bottom fishery, which is mostly carried out by divers, and by intertidal rocky substrate collectors with the targeted resources of mollusks, crustaceans, and algae of high economic value.

An Artificial Reef (AR) is a man-made underwater structure designed to protect, enhance, or restore components of marine ecosystems [4]. In recent years, ARs have been used with different objectives, including coastal protection (natural disasters), benthic life protection (i.e., against trawling) $[5,6]$, conservation [7], protecting sensitive habitats [8], restoration of damaged coastal ecosystems [9-12], to aggregate fish [13,14], increase fish stocks [15], bio-filtration [16], tourism-associated activities [17,18], coastal management [19], fish gathering (to facilitate catch) [20], for the creation of potential networks of marine protected areas [21], to improving artisanal fisheries [22], and other fishery-associated activities. AR techniques have been proposed as promoters of hard bottom-associated organisms (epi-fauna and epi-flora) [23], and potentially associated demersal, mainly fish, species, by providing needed habitat (substrate) and/or refuge.

The 1991 and 2013 Fishery Acts of Chile set basic management tools for institutionalizing fishery activities by detailing regulations to ensure the conservation of marine resources. All these regulations are applicable to marine species, but at present there are no criteria for the development of ARs as this technology has only been considered in the Fishery law since 2015. The concept of AR technology is now in Chile's Fishing Act 18.892, and their installation is mentioned in two articles: article 9 letter (e) and article 48 letter (b). However, the government authority has not yet adopted the implementing administrative guidelines.

The decline of marine fishery resources, due to overexploitation and increased demand, necessitates that Chile initiates the implementation of complementary technological production alternatives. In recent years, Chile has seen an increased demand for traditionally consumed benthic shellfish resources making it urgent to increase their supply through methods which will ensure a greater resource biomass without negative environmental impacts (Subpesca Annual Report 2017). 
The HCLME off the Chilean coast is one of the most productive ecosystems in the world with high primary production levels [24-26]. These natural conditions are particularly ideal for the implementation and development of a system that could capture this rich environmental organic carbon and transform it into marine animal biomass for human consumption. Given this scenario, the implementation of ad hoc ARs within the HCLME is an excellent marine development option to increase the production of benthic resources along the Chilean coastal waters. ARs could allow for the replenishment of the local benthic (sea-bottom) life by providing new substrate to larvae and adults of epi-benthos (hard-bottom loving organisms, both macro-algae, and invertebrates), and associated demersal fish [27].

Many definitions exist about ARs depending on their use or purpose [28,29]; Goldschmid and Yip [30] summarized the pros and cons of ARs. The pros include (1) providing shelter, calm waters, and influencing water currents so that fish save energy while swimming against the current; (2) attracting smaller organisms, which are vital sources of food for different marine species; (3) serving as visual reference points for fish that forage away from the reef and increase over the entire reef area, which can host a larger number of reef fish; (4) enhancing existing rough bottom habitat and developing quality fishing grounds close to accessible areas by properly constructed and buoyed ARs; and (5) increasing fisher populations in the harbor due to AR construction leads to an increase in fish harvesting [31].

Although ARs built upon modern concepts usually do not have many negative impacts, problems may occur if they are poorly designed and deployed. Nevertheless, the cons are summarized as follows: (1) presence of pollutants in the building material and/or substrate, (2) interference with fishing activity if AR areas are not properly marked, and (3) artificial reefs would have to be built on a case-by-case basis due to the degree of difference in the bottom condition (Yozzo et al. [32] in Friend and Cummins [31]).

There has been a pilot project on AR deployment in Caleta Pisagua in 2012 and 2013, which concluded that the AR deployment can increase the production and biodiversity of benthic resources (https://www. conicyt.cl/wp-content/themes/fondef/encuentra_proyectos/PROYECTO/07/I/D07I1032.html). However, fishermen's perceptions on such deployment have never been studied. Thus, to ensure the future sustainability of artisanal fishery on benthic resources, this study aims to learn fishermen's opinions on deploying ARs in northern Chile Caleta Pisagua AMERB, using artisanal fisherman interviews.

\section{Materials and Methods}

\subsection{Data Collection}

Literature reviews and artisanal fishermen interviews were used in this study to investigate the fishermen's opinions on AR deployment in the Caleta Pisagua AMERB. Literature reviews addressed two main subjects: (1) the collection of information on social and fishery-related aspects of Caleta Pisagua and the Pisagua AMERB, and (2) collecting information on the implementation of ARs. Official yearly reports (National Fishery Service), fishery research project reports, and scientific literature were used to extract needed data on species and species-specific landing data. Intensive search in books, scientific journals, workshop reports, and expert presentations was conducted to summarize the legislation and implementation of ARs and on the pros and cons of AR deployment.

\subsection{Interviews of Caleta Pisagua Fishermen}

Artisanal fishermen in this area include boat fishermen, shellfish divers, shore collectors, and sailor helpers, all of whom are organized into a union and entitled to an AMERB with an area of 155.4 ha where approximately $61 \%$ of this area consists of soft (sandy) substrate. All fishery statistics related to Caleta Pisagua are included in the total harvest of all AMERBs, and both are included in the Tarapacá Region landings [33]. There are 23 AMERBs in this region with a combined area of $1665.5 \mathrm{ha} ; 9.3 \%$ of this area is included in the Pisagua management area.

The survey was conducted using personal interviews with 30 out of 35 artisanal fishermen from the Caleta Pisagua area between July and August 2016. The questionnaire consisted of four main parts. The first part included age, activity, fishing experience, and other information; the second part included 
the activity, transit time to the fishing zone, type of fishing gear used, time, and diving depth; the third part was the resource profile that includes the main species, the secondary species, and species seldom to be harvested; and the fourth part was related to the personal position with respect to artificial reef technology (Interview questionnaire can be found in Appendix A).

The questionnaire was designed to collect the information necessary for further analyses based on examples from the bibliography such as those made by the National Statistics Institute (INE) of Chile [34]. The responses to questionnaires from the artisanal fishermen of the Caleta Pisagua were analyzed by using SPSS [35]. A Chi-Square test was used to examine the homogeneity of distribution among groups.

\section{Results}

The landings of marine fisheries in Chile from 1950 to 2016 peaked in 1994 at 7,558,571 tons, and decreased thereafter to the lowest value of 1,886,474 tons in 2014. However, mollusk landings and other species have increased due to the development of aquaculture in southern Chile [36].

\subsection{Catch Composition in Caleta Pisagua}

There were 60 species caught by the fisheries in the Chilean AMERBs [37]; 54 of these species (90\%) were found within the boundaries of Caleta Pisagua, including the AMERB. Of these 54 species, $82 \%$ correspond to benthic species that require hard substrate as refuge in one or more of their life stages (Table 1) [38].There were six main target benthic resources in Caleta Pisagua: the "locate" snail (Thais chocolata), the northern octopus (Octopus mimus), the crab (Romaleon polyodon), the sea urchin (Loxechinus albus), the Chinese hat limpet (Fissurella sp.), the "loco" snail (Concholepas concholepas), and various species of macro-algae. However, annual landings of these species fluctuated largely from 2003 to 2016 (Figure 1) [39]. Since all of these species have high value and great market potential, each species has its own regulation and quota established according to the management plan proposed by special expert groups and instituted by the Sub-Secretariat of Fisheries. Secondary resources are Pyura chilensis ("piure"), Austromegabalanus pssitacus ("picoroco"), mussels ("cholga") (Aulacomya atra, Mytilus chilensis), and "choro" (Choromytilus chorus) (Table 1).

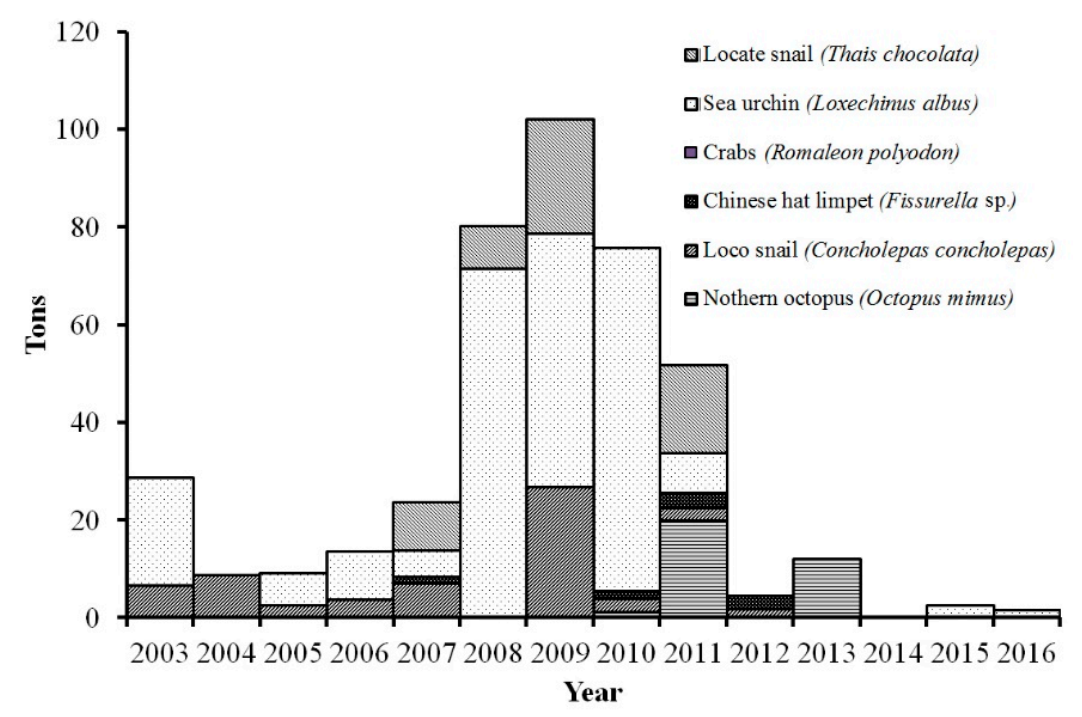

Figure 1. Species-specific landings in Caleta Pisagua AMERB from 2003 to 2016. Source: SERNAPESCA (2017) [39]. 
Table 1. Pisagua base line. Source: Informe FIC, 2015 [38]. *: Rocky substratum is not required.

\begin{tabular}{|c|c|c|c|c|c|}
\hline Scientific Name & Common Name & Local Common Name & Scientific Name & Common Name & Local Common Name \\
\hline Fish & & & Shellfish & & \\
\hline $\begin{array}{l}\text { Aplodactylus } \\
\text { punctatus }\end{array}$ & Marblefishes & Jerguilla & Aulacomya atra & Blue mussel & Cholga \\
\hline Aunchenionchus sp. & - & Chasque o chalaco & $\begin{array}{l}\text { Austrolittorina } \\
\text { araucana }\end{array}$ & Sea snail & Caracol \\
\hline $\begin{array}{l}\text { Cheilodactylus } \\
\text { veriegatus }\end{array}$ & $\begin{array}{l}\text { Peruvian } \\
\text { morwong }\end{array}$ & Pintacha & Chiton sp. & Sea cradles & Apretador \\
\hline $\begin{array}{l}\text { Doydixodon } \\
\text { laevifrons }\end{array}$ & - & * Baúnco & $\begin{array}{l}\text { Concholepas } \\
\text { concholepas }\end{array}$ & Chilean abalone & Loco \\
\hline $\begin{array}{l}\text { Hypsoblennius } \\
\text { sordidus }\end{array}$ & $\begin{array}{l}\text { Combooth } \\
\text { blenny }\end{array}$ & Trombolito robusto & $\begin{array}{l}\text { Crassilabrum } \\
\text { crasilabrum }\end{array}$ & Sea snail & Caracol blanco \\
\hline Isacia conceptionis & Cabinza grunt & Cabinza & Fisurella maxima & $\begin{array}{l}\text { Giant keyhole } \\
\text { limpet }\end{array}$ & Lapa reina \\
\hline $\begin{array}{l}\text { Paralabrax } \\
\text { humeralis }\end{array}$ & Rock bass & Cabrilla & Nassarius gayi & Sea snail & Caracol dentado \\
\hline $\begin{array}{l}\text { Paralichthys } \\
\text { microps }\end{array}$ & $\begin{array}{l}\text { Large-tooth } \\
\text { flounders }\end{array}$ & Lenguado ojo chico & Priene rude & Peruvian triton & Caracol peludo \\
\hline Pinguipes chilensis & $\begin{array}{l}\text { Chilean } \\
\text { sandperch }\end{array}$ & ${ }^{*}$ Rollizo & Tegula atra & Sea snail & Caracol negro \\
\hline Prolatilus jugularis & $\begin{array}{l}\text { Pacific } \\
\text { sandperch }\end{array}$ & * Blanquillo & Thais chocolata & Sea snail & Caracol locate \\
\hline Scathichthys gigas & - & * Borrachilla & Tonicia chilensis & Chilean chiton & Chitón \\
\hline Sciaena deliciosa & Delicious drum & ${ }^{*}$ Roncacho & Turritela cingulata & Sea snail & Cachito \\
\hline Sebastes capensis & Cape redfish & Cascajo & Octopus & & \\
\hline Seriolella violacea & Palm ruff & * Cojinova & Octopus mimus & Gould octopus & Pulpo \\
\hline Sicyases sanguineus & Marine clingfish & Pejesapo & Coral & & \\
\hline $\begin{array}{l}\text { Trachurus } \\
\text { symetricus murphy }\end{array}$ & $\begin{array}{l}\text { Pacific jack } \\
\text { mackerel }\end{array}$ & * Jurel & $\begin{array}{l}\text { Anemonia } \\
\text { alicemarthinae }\end{array}$ & Sea anemone & Actinia roja \\
\hline $\begin{array}{l}\text { Tripterygion } \\
\text { chilensis }\end{array}$ & Triplefin blenny & $\begin{array}{l}\text { * Trombolillo de tres } \\
\text { aletas }\end{array}$ & Phymantea pluvia & Coral & Anemona de mar \\
\hline Crustacea & & & Phymantea sp. & Coral & Actinia blanca \\
\hline $\begin{array}{l}\text { Allopetrolisthes } \\
\text { punctatus }\end{array}$ & Porcellanid crab & Cangrejo & Echinoderm & & \\
\hline $\begin{array}{l}\text { Austromegabalanus } \\
\text { psittacus }\end{array}$ & Giant barnacle & Picoroco gigante. & Heliaster heliantus & Starfish & Sol de mar \\
\hline Balanus balanus & Acorn barnacle & Picoroco & Loxechinus albus & Sea urchin & Erizo rojo \\
\hline Cancer setosus & Crab & Jaiba peluda & $\begin{array}{l}\text { Meyenaster } \\
\text { gelatinosus }\end{array}$ & Large spiny star & Estrella de mar \\
\hline $\begin{array}{l}\text { Cancer coronatus } \\
\text { Homalapsis plana }\end{array}$ & $\begin{array}{l}\text { Crab } \\
\text { Common crab }\end{array}$ & $\begin{array}{l}\text { Jaiba reina } \\
\text { Jaiba mora }\end{array}$ & $\begin{array}{l}\text { Patiria chilensis } \\
\text { Algae }\end{array}$ & Starfish & Estrella de mar \\
\hline $\begin{array}{l}\text { Ovalipes } \\
\text { trimaculatus }\end{array}$ & Portunid crab & Jaiba nadadora & Coralina chilensis & - & Alga calcárea \\
\hline Paguristes weddelli & Crab & Cangrejo ermitaño & Lessonia trabeculata & Brown algae & Huiro palo \\
\hline $\begin{array}{l}\text { Rhyncocinetes } \\
\text { typus }\end{array}$ & Rock shrimp & Camarón rojo & $\begin{array}{l}\text { Rhodymenia } \\
\text { corallina }\end{array}$ & Red algae & Alga roja \\
\hline $\begin{array}{l}\text { Taliepus dentatus } \\
\text { Polychaete }\end{array}$ & Spider crab & * Panchote & $\begin{array}{l}\text { Rhodymenia sp. } \\
\text { Others }\end{array}$ & Red algae & Alga roja \\
\hline Polychaete & Polychaetes & * Poliqueto & $\begin{array}{l}\text { Diaulula } \\
\text { punctuolata } \\
\text { Pyura chilensis }\end{array}$ & $\begin{array}{l}\text { Sea slug } \\
\text { Sea squirt }\end{array}$ & $\begin{array}{l}\text { Nudibranquio } \\
\text { Piure }\end{array}$ \\
\hline
\end{tabular}

\subsection{Interview Results}

The results of interviews of the Caleta Pisagua artisanal fishermen are summarized as follows:

\subsubsection{Fishermen Profile}

The age of the Caleta Pisagua artisanal fishermen ranged from 18 to over 60 years old; this age structure was biased (Chi-Square test, $p<0.05$ ) as 30\% of the fishermen were between ages of 50 and $59,26.7 \%$ were older than age $60,23.3 \%$ were between ages 40 and 49 , and only $13.3 \%$ were between ages 30 and 39 and $6.7 \%$ were between ages 18 and 29 .

Forty percent of the interviewees had more than 30 years of fishing experience, $26.7 \%$ of them had $25-30$ years of experience, $26.7 \%$ had $15-24$ years of experience, and only $6.6 \%$ had $5-14$ years of experience. 


\subsubsection{Activity Profile}

With regard to the type of job, five groups were identified, namely, divers $(50 \%)$, shore collectors and seafood pickers (10\%), helpers (13.3\%), and fish catchers (23.3\%). Regarding to the worker type, only $13.3 \%$ work alone and $86.7 \%$ of the interviewees do not work alone. Those who work alone corresponded to actual fish catchers.

Three sets of working hours were categorized for the interviewees: between 3 and $6 \mathrm{~h}(23.3 \%)$, 6 and $9 \mathrm{~h} \mathrm{(46.7 \% )}$ and 9 and $12 \mathrm{~h}(30 \%)$. The artisanal fishermen in Caleta Pisagua did not have fixed schedules for fishing and their activities were mainly dependent on the weather conditions.

\subsubsection{Resource Profile}

Caleta Pisagua fishermen captured a variety of resources depending on the seasonality of the major resource and its legal provisions. In total, $33.3 \%$ of the catches were three main species: "loco" (the snail), "erizo" (the sea urchin), and octopi; $26.7 \%$ were various species of fish, and $20 \%$ were only octopi and "loco" (Figure 2a). Among the secondary catches, 23.3\% were "lapas" (Chinese hat limpet Fissurella sp.) and snails (Austrolittorina sp., Crassilabrum sp., Nassarius sp., Tegula atra, Thais chocolata, Turritella sp.), 23.3\% were blue mussel (Aulacomya ater), 20\% were clams (bivalve), $16.7 \%$ were the tunicate, sea squirt or "piure" (Pyura chilensis); $10 \%$ were the algae "huiro" (Lessonia sp.) including chalky algae (Corallina sp.) and red algae (Rhodymenia sp.), and 6.7\% were various species of fish (Figure 2b).

Regarding product sales, $90 \%$ of the interviewees deliver their products to a single beach auctioneer, $6.7 \%$ to the national market, and $3.3 \%$ to the international market. For the final buyer, $83.3 \%$ of interviewees responded that processing plants are the final buyers, and $16.7 \%$ mentioned that the buyers are private persons.

With respect to the impacts of climate events such as El Niño in marine resources, $90 \%$ of the interviewees agreed that climate events have effects, $6.7 \%$ stated that they had no effects, and $3.3 \%$ did not know.
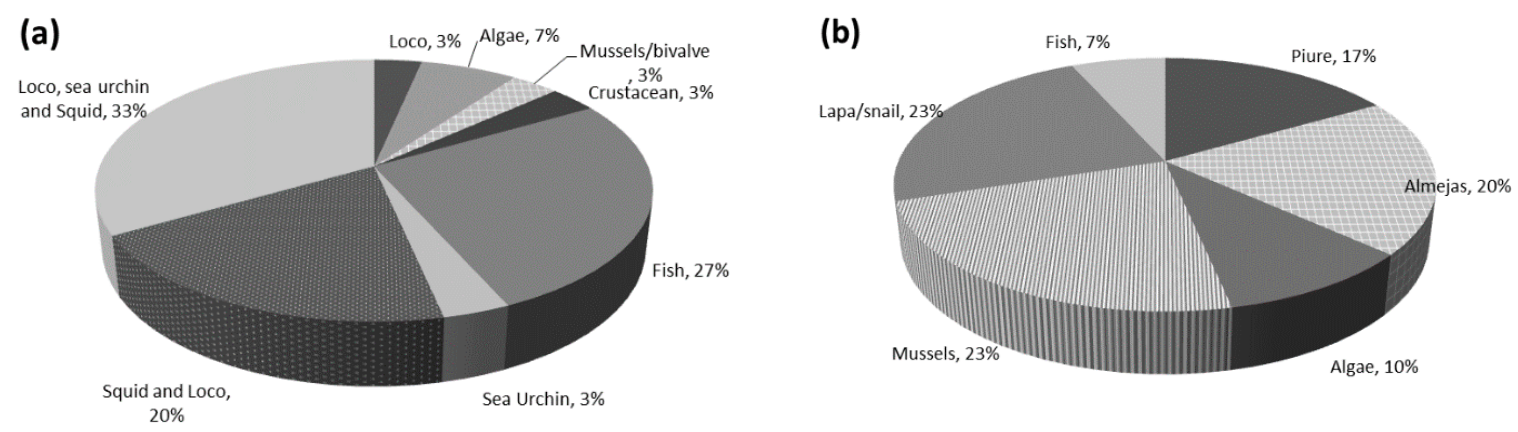

Figure 2. (a) Main species and (b) secondary species caught by artisanal fishermen in Caleta Pisagua AMERB.

\subsubsection{Artificial Reef Profile}

With regard to the acceptance of ARs as an alternative for improving the production of benthic marine resources, $83.3 \%$ of the interviewees accepted the AR technology, while $16.7 \%$ of the interviewees rejected it. A Chi-Square test indicated that the acceptance rate was significantly higher than $50 \%(p<0.05)$ and the acceptance rate had no significant association with the age group of fishermen $(p>0.05)$.

As for the reason for preferring AR technology, $40 \%$ of the interviewees responded "more income", $30 \%$ mentioned "more income and catch", 16.7\% did not like this technology, $6.7 \%$ preferred the technology because they could have more buyers, and 3.3\% preferred more access to resources. A total of $53.3 \%$ of the interviewees preferred both (natural and artificial) substrates, $26.7 \%$ preferred natural, and $20 \%$ preferred an artificial substrate. 
Regarding the place for the deployment of AR, 33.3\% of the interviewees favored near the shore, $16.7 \%$ preferred far from the shore, while $40 \%$ preferred both places (depending on the resources). Regarding the depth, $70 \%$ of the interviewees answered installation at depths of 11 to $20 \mathrm{~m}$, while $23.3 \%$ preferred depths of 21 to $30 \mathrm{~m}$. Regarding the preference in building AR, $90 \%$ of the interviewees preferred self-build, $6.7 \%$ preferred self-build or purchase, and 3.3\% did not agree to building.

\section{Discussion}

Spanier et al. [7] indicated that 54 of the 60 exploitable resource species found in all Chilean AMERBs occur within the boundaries of the Caleta Pisagua AMERB. Eighty percent of these species are sedentary resources that require hard substrate (Table 1) as their habitat or refuge in one or more of their life stages, suggesting that the full utilization of these resources depends on the availability of substrate. Both main and secondary benthic resources exploited by the Caleta Pisagua fishermen need the supply of hard substrate as their habitats. Therefore, deploying AR may result in the socioeconomic improvement of local artisanal fishermen with the increase in typical benthic resources (shellfish, fish, and algae) due to the consistency of high levels of primary production from the HCLME. This is a quite unique case since most relevant fishery-related use of ARs elsewhere in the world has been reported mainly as fish-gathering devices [40]. Based on the mean density of "loco" $\left(0.217 \mathrm{~kg} / \mathrm{m}^{2}\right)$ in Tacna area, Peru (150 km in straight line north of Pisagua) [41], the estimated biomass of "loco" was 37 tons if 100 ARs (17 $\mathrm{m}^{2}$ for each) were deployed in the AMERB of Caleta Pisagua. Even only $10 \%$ of the biomass was harvested in the $1700 \mathrm{~m}^{2}$ area, the estimated catch of 3.7 tons was larger than the landing of 1.8 tons for the entire AMERB (153.8 hectares) in 2012.

In relation to the legal issue, the analysis of Caleta Pisagua artisanal fishermen as a function of the Chilean application of AR is relevant to the official need of information to develop the Official Legal Guidelines to be later published in the Official Gazette, as required by law. The implementation of AR in Chile will require further marine policy development, since there are currently no applicable regulations, except perhaps those related to marine pollution and legal size and/or reproductive status of several marine species. The present legal text of the 2015 Act on Fishery and Aquaculture allows the use of ARs in artisanal fisheries reserved areas. However, the general Act's Official Guidelines have not been yet published in the Official Government Gazette. It is conceived that basic oceanographic, biological, ecological, and practically-derived knowledge shall be taken into account.

The interviews of Caleta Pisagua fishermen rendered useful information for the implementation of the AR technique in Pisagua. First, while the concept of AR is positively understood and well taken by the artisanal fishermen who are members of the syndicate that have the rights over the Caleta Pisagua AMERB, some of them find it important to have continued access to the natural settings outside the AMERB. Many older members suggested that an immediate innovation in the way fishermen exploit the resources-the surplus of naturally available, hard bottom species for the epi-biota-is urgent.

Moreover, the interviewees expressed that the central and regional governments should invest in infrastructure. In particular, a municipal water treatment plant is an urgent need of construction. This is a long overdue element that will even be critical with the greater AR output of fisheries resources requiring initial processing in situ. It is hoped that infrastructure development can be made after installation of ARs when full production of benthic resources is achieved. Currently, without AR, the socioeconomic advantages of harvesting target species growing within the AMERBs on naturally derived hard substrates, have met with mixed problems, despite officially approved regulations and periodically evaluated management plans [17].

Regarding the fishermen profile, the age structure data show a mature population of artisanal fishermen where the majority are older than 50 years and only $10 \%$ are young, indicating that present activity in the site is heavily relied on aged people and fundamental socioeconomic changes are not carried out to retain young people. Most interesting is that with reference to the type of activity, the main one is diving with divers conforming half of the surveyed group, which together with their assistants or helpers, make up $63 \%$ of the total surveyed artisanal fishermen. This group is obviously 
benefitted from the implementation of the AR within their AMERB because they are the ones that normally work directly on the hard bottom resources. Actual fishermen who will also be benefitted with the increase in demersal fish attracted by ARs for various purposes [42].

Regarding fishermen's working practices, the majority of the interviewees in Caleta Pisagua carry out their work in teams, a fact that is vital for the implementation of the system of ARs both in relation with their management and the fair and ordered utilization of the resources. In relation with the same point, Caleta Pisagua fishermen already have experience in the administration of their AMERB which was established in 2000. It is also important to mention that for $70 \%$ of the Caleta Pisagua artisanal fishermen, fishing is their only activity; there are no other work opportunities that would come handy in times of resource bans or rough seas. These factors continue maintaining the village population in the limits of vulnerable poverty, conditions that make the implementation of technological alternatives that could improve their livelihood urgent. The productive limitations of the present AMERB system require that fishermen must also move farther away from the cove to search for hard bottom resources in areas of free access.

All Caleta Pisagua artisanal fishermen have no fixed working hours or fixed agendas. The working hours fully depend on the weather conditions. This will lead to idle time when weather conditions do not allow fishermen to work at sea. Installing AR should reduce the working hours and the danger of shipwrecking far from the coast, and improve their quality of life. Under certain weather conditions, they would even be able to work within the bay.

The majority of Caleta Pisagua fishermen harvest more than one marine resource, depending on the established regulations for each species. Besides increasing the biomass of resources that have been traditionally harvested, ARs could increase the biomass of secondary species, $73 \%$ of which require hard substrate for their development. With proper management, these secondary species could be the solution when any management measure-such as banning fishing-affects the access to the main resources.

With reference to the main question "Do you like the artificial reef technology?", the majority of fishermen had positive answers (83.3\%). Fishermen learned from their experience that an increase in the required substrate will result in an increase in biomass of both of their principal target species as well as of secondary resources. They further appreciated that with proper management, a constant extractive activity could be maintained, and their annual income could be increased. This is important for those fishermen that sell their harvest to the village and neighbor villages, and the city's restaurants, because the fishing activity in Caleta Pisagua is directly related to the summer tourist activity.

The major reasons that fishermen favor the installation of AR are the increase in income and catch, easy access, easy supervision, less time involved, and lower level of hardship in terms of general activity. A good degree of a sense of team work was also revealed, which is most favorable for the success of their AMERB enterprise, once it is implemented by ARs.

The distance at which the ARs could be installed will depend on the main target species, although the majority of fishermen expressed that the ARs should be installed near inshore so that harvest could even be performed in bad weather. Although the fishermen accepted the AR, they considered that their fishing effort should be efficient to combine both harvests on the AR resource and on the neighboring natural hard substrates. For fishermen interested in the diverse species of shellfish, main and secondary resources (bottom settlers and fish), snails, limpets, crab, sea-squirt, mussel, barnacles, octopi, anemones, and macro-algae, coincided in that the depth of ARs installation should not exceed $30 \mathrm{~m}$, with the majority coinciding with the range between 11 and $20 \mathrm{~m}$ deep. These depths are considered ideal both by divers and net and hook fishermen, and coincide with the depth at which both the main and secondary resources occur and the maximum allowed diving depth. The experience of Caleta Pisagua AMERB fishermen indicates that the highest landings of two of the most important resources (the "loco" snail and the edible sea urchin), are obtained at depths between 5 and $15 \mathrm{~m}$ [37]. 
It is important to mention that approximately $98 \%$ of the snail "loco" landings in the Pisagua area ( 27 ton) were harvested from Caleta Pisagua AMERB in 2009 [43]. This resource was under a national extractive ban from 2012 to 2017, but the ban did not apply to AMERBs, marine reserves or protected areas of multiple uses with a valid management plan. In this manner, AR could help recover the natural population and improve landings, reducing the effect of official restrictive measures.

Taking into account the levels of photosynthetic fixed carbon $C$ and extensive eutrophic bottoms, it is proposed that for all Chilean management areas, primary food availability should not be a limiting factor for the improvement of landings [44-47]. Thus, the surface area allotted to AR during a primary phase should not be larger than the amount considered for the development of aquaculture within the AMERBs, which corresponds to $20 \%$ of its total area [43]. One of the main environmental problems that the introducing of AR could face in Caleta Pisagua relates to the impact of the sporadic, warm El Niño events accompanied more or less by strong sea surface temperature anomalies which directly affect the settled populations, disturbing their reproduction, larval development and settling; mobile species (fish, crabs, prawns, octopi) would probably migrate south or in deeper waters. According to the fishermen of Caleta Pisagua, during the last El Niño event of 2015-16, the structure of the neritic community changed along with the arrival of a previously unknown fish species of important economic value.

As a collateral social effect, AR would allow natural resources to benefit the whole community by providing a stable, more predictable output; this stability is necessary for a healthy, active, and progressive human organization $[48,49]$. In this context, isolated and remote human communities-far from larger cities such as Caleta Pisagua but with great potential to generate economic returns-should be supported by the central and local governments with the initial basic infrastructure needed to process and add value to its products. In the particular case of Caleta Pisagua, our research uncovered that the artisanal fisherman union has the elements of a processing plant in store which paradoxically cannot be utilized because the municipality lacks a sewage treatment plant, and thus, it cannot obtain the sanitary permits to elaborate their marine resources. This vicious circle continues to persist, making it impossible for the union to opt for a seal of origin for its products. It is hoped that by the time the AR gets its place in Caleta Pisagua, this limitation would already be eliminated.

The implementation of AR in Caleta Pisagua could further develop into a microscale example of the provisions needed to reach the sustainable goals proposed by the United Nations as challenges for the year 2030. The main objectives that could be attained by ARs are those related to reducing poverty, hunger, promoting gender equality, decent work, and economic growth through the development of industry and implement of innovative infrastructure to mitigate the impact of climate change. It is hoped that the Caleta Pisagua example can be applied to other fishing villages in Northern Chile that have similar situations.

\section{Conclusion and Recommendations}

The results derived from this study indicated that ARs could play an important role in the socioeconomic development of the artisanal fishermen of northern Chile. The fundamental factors to the development of AR are as follows: oceanographic conditions of high productivity, the decrease that fisheries have generally exhibited, the present conservation-oriented coastal territorial management (AMERBs), the highly organized artisanal fishermen, the diversity and high reproductive capacity of hard bottom-associated species, and the high acceptance rate of the use of ARs among the Caleta Pisagua fishermen.

Two general recommendations for the implementation of the artificial reef system in Chile are as follows:

1. A specific management plan for ARs should be developed for both main and secondary species with systematic and direct evaluations. Furthermore, an exploitation program for each species that considers annual quotas, seasonal closure, minimum size limit, and annual reports on the stock status must be applied. 
2. Criteria for deploying AR should be implemented considering four stages: (1) site survey and selection, (2) material selection and reef design, (3) reef construction and deployment, and (4) evaluation of effectiveness. The carrying capacity of site, currents, bathymetry, and geomorphology should be developed before AR installation. The next marine policy step with respect to AR in Chile is suggested to be the formulation of official guidelines that regulate this activity and promote its development.

Author Contributions: Conceived and designed the experiments: C.E., V.A.G., K.-M.L. Performed the experiments: C.E., V.A.G. Analyzed the data: C.E., K.-M.L. Contributed reagents/materials/analysis tools: C.M., P.P. Wrote the paper: C.E., K.-M.L. All authors have read and agreed to the published version of the manuscript.

Funding: University of Concepción, Office of International Affairs. Fondo de Innovación para la Competitividad Regional (FICR). Código BIP 30116701-0 Proyecto: Generación de arrecifes artificiales para el incremento de la producción y biodiversidad en el área de manejo de Pisagua, y la creación de servicios turísticos de intereses especiales.

Conflicts of Interest: The authors declare that the research was conducted in the absence of any commercial or financial relationships that could be construed as a potential conflict of interest.

\section{Appendix A. Interview Questionnaire}

\section{FISHERMEN PROFILE:}

Fishermen Interview

Name:

Date:

1. Age (years)

18 to 29 _ 30 to 39 40 to 49 50 to 59 more than 60

2. Experience (years)

II. ACTIVITY PROFILE:

3. Type of work
_ Sailor Diver Collector shore Seafood picker Helper Fisherman

4. Do you work alone?

_ Yes__ No

5. How many people work with you?

_ 0 __ more than 1 how many?

6. It is your unique work?

_ Yes __ No

7. How many time do you use for to work?(hours)

_ 3 to $6 \_6$ to $9 \_9$ to 12

8. Time under water (minutes)

_ 0 to $30 \_30$ to $60 \_$not apply

9. Number of inmersions

$\overline{10 .}^{3}{ }_{\text {Schedule }}^{4}{ }^{5}$ no apply

Free time __ Fixed time

11. Day limited?

Yes __ No

III. RESOURCES PROFILE:

12. What specie do you work?

__ Loco __ Algae __ Bivalve __ Crustacean __ Fishes __ Sea urchin

__ Squid plus loco ___ Loco, sea urchin and squid.

13. Secondary species?

__ Piure __ Clams __ Algae __ Mitilidos__ Lapa/Snails __ Fish

14. All people works in same specie?

Yes __ No

15. What is the final destination of your products?

__ Family __ Restaurant___ Big cities 
16. What is the most difficult extracted specie?

__ Squid __ Loco/snail __ Algae __ Bivalve __ Crustacean __ Fish

17. What is a most easy to catch species?

__ Squid __ Loco __ Algae __ Bivalve __ Sea urchin

18. Do you have problems in El Niño Event?

_ Yes __ No __ do not know what:

19. How do you transport your products?

People come and get them __ we take them to the city do not know

20. What is the final market for your products?

__National __ Auctioneer __ International

21. Who is the buyer?

Particular people __ Processing plants

IV. AR PROFILE:

22. Do you like AR Tech?

Yes _ No

23. If you want this technology, what do you like?

_ biomass __ Income __ Access _ buyers _ biodiversity _ none biomass and income

24. What changes do you make?

_ Design __ Place __ Amount _ f free contamination materials __ Design/place

_ design/place/amount

25. If you can choose natural or AR substrate

_ Natural _ _ ART _ B Both

26. According to your field observations, which substrate is best for fixing organisms?

_ Natural __ ART _ B Both _ _ No know

27. What is better, build or buy AR?

_ to buy _ _ to build __ Both

28. Preference for installation in distance

_ Near to shore __ Far to shore __ Both __ none

29. Preference for installation in depth (meters)

0 to $10 \ldots 11$ to $20 \ldots 21$ to 30

30. Do you recommend this technology?

Yes _ No

\section{References}

1. Subsecretaría de Pesca y Acuicultura (SERNAPESCA). Áreas de Manejo y Explotación de Recursos Bentónicos. Available online: http://www.subpesca.cl/institucional/602/w3-article-79853.html (accessed on 5 February 2017).

2. Moreno, A.Y.; Revenga, C. Sistema de Gestión Pesquera Artesanal Basado en Derechos de Uso Territorial en Chile; The Nature Conservancy: Arlington, VA, USA, 2014; p. 36.

3. De Pesca, S. Reglamento sobre Áreas de Manejo y Explotación de Recursos Bentónicos N 355; Ministerio de Economía Fomento y Reconstrucción: Santiago, Chile, 1995; p. 16.

4. Seaman, W.; Lindberg, W.J. Artificial Reef in Encyclopedia of Ocean Sciences, 2nd ed.; 2009; pp. $226-233$. [CrossRef]

5. Allemand, D.; Debernardi, E.; Seaman, W.J. Artificial reefs in the Principality of Monaco: Protection and enhancement of coastal zones. In Artificial Reefs in European Seas, Chapter 9; Jensen, A.C., Collins, K.J., Lockwood, A.P.M., Eds.; Kluwer Academic Publishers: Dordrecht, The Netherlands, 2000; pp. 151-166.

6. Seaman, W. Artificial Reef Evaluation: With Application to Natural Marine Habitats; CRC Press: Boca Raton, FL, USA, 2000; p. 260.

7. Spanier, E.; Lavalli, K.L.; Edelist, D. Artificial reefs for lobsters: An overview of their application for fisheries enhancement, management, and conservation. In Artificial Reefs in Fishery Management; Bortone, S.A., Brandini, F.P., Fabi, G., Otake, S., Eds.; CRC Press: Boca Raton, FL, USA, 2011; Chapter 6; pp. 77-109.

8. Fabi, G.; Spagnolo, A. Artificial Reefs in the Management of Mediterranean Sea fisheries, Artificial Reefs in Fisheries Management; CRC Press: Boca Raton, FL, USA, 2011; pp. 167-181. 
9. Allemand, D.; Ferrier-Pages, C.; Debemardi, E. Protection and management of the waters along the coast of Monaco. Oceanogr. Lit. Rev. 1998, 3, 546.

10. Antsulevich, A.E. Artificial reefs project for improvement of water quality and environmental enhancement of Neva Bay (St.-Petersburg County Region). Bull. Mar. Sci. 1994, 55, 1189-1192.

11. Charbonnel, E.; Harmelin, J.G.; Carnus, F.; Direac'h, L.L.; Ruitton, S.; Lenfant, P.; Beurois, J. Artificial reefs in Marseille (France, Mediterranean Sea): From complex natural habitats to concept of efficient artificial reef design. Braz. J. Oceanogr. 2011, 59, 177-178. [CrossRef]

12. Iannibelli, M.; Musmarra, D. Effects of anti-trawling artificial reefs on fish assemblages: The case of Salerno Bay (Mediterranean Sea). Ital. J. Zool. 2008, 75, 385-394. [CrossRef]

13. Bohnsack, J.A.; Sutherland, D.L. Artificial reef research: A review with recommendations for future priorities. Bull. Mar. Sci. 1985, 37, 11-39.

14. Lök, A.; Gül, B.; Ulaş, A.; Düzbastılar, F.O.; Metin, C. Diel variations on the fish assemblages at artificial reefs in two different environments of the Aegean Sea (Western Coast of Turkey). Turk. J. Fish. Aquat. Sci. 2008, 8, $79-85$.

15. Chuang, C.T.; Guinea, E.; Kuo, H.H. An impact and management study of Taiwanese artificial reef deployment. In Proceedings of the IIFET 2008 Vietnam Proceedings, Nha Trang, Vietnam, 22-25 July 2008; p. 12.

16. Gomoiu, M.T. Donnees preliminaires sur la structure et le role d'une communaute epibionte formee sur le substrat artificial. Rapp. Comm. Int. Mer Méditerr. CIESM. Monaco 1986, $30,17$.

17. Stotz, W.; Caillaux, L.; Cecchi, F.; Escobar, M.; Garay, R.; Lancellotti, D.; Valdebenito, D.; Zuñiga, S. Evaluación del Proceso de Implementación de la Medida de Administración Áreas de Manejo y Explotación de Recursos Bentónicos (AMERB) en las Regiones III y IV y la Elaboración de una Propuesta de Mejoramiento de la Medida. Proyecto FIP 2005-34 Grupo de Ecología y Manejo de Recursos; Facultad de Ciencias del Mar, Universidad Católica del Norte: Coquimbo, Chile, 2008; p. 196.

18. Tessier, A.; Dalias, N.; Lenfant, P. Expectations of professional and recreational users of artificial reefs in the Gulf of Lion, France. J. Appl. Ichthyol. 2015, 31, 60-73. [CrossRef]

19. Pioch, S.; Kilfoyle, K.; Levrel, H.; Spieler, R. Green marine construction. J. Coast. Res. 2011, 61, $257-268$. [CrossRef]

20. Sánchez-Jeréz, P.; Fernández-Jover, D.; Uglem, I.; Arechavala-López, P.; Dempster, T.; Bayle-Sempere, J.T.; Nilsen, R. Coastal fish farms as fish aggregation devices (FADs). In Artificial Reefs in Fishery Management; Taylor \& Francis Group, CRC Press: Boca Raton, FL, USA, 2011; pp. 187-208.

21. Claudet, J.; Pelletier, D. Marine protected areas and artificial reefs: A review of the interactions between management and scientific studies. Aquat. Living Resour. 2004, 17, 129-138. [CrossRef]

22. Santos, M.P.N.D.; Seixas, S.; Aggio, R.B.M.; Hanazaki, N.; Costa, M.; Schiavetti, A.; Azeiteiro, U.M. A pesca en quanto atividade humana: Pesca artesanal e sustentabilidade. Rev. Gest. Costeira Integr. 2012, 12, 405-427. [CrossRef]

23. Thorson, G. Bottom communities (sublittoral or shallow shelf). Treatise Mar. Ecol. Palaeoecol. 1957, 67, 461-534.

24. Chen, J.L.; Chuang, C.T.; Jan, R.Q.; Liu, L.C.; Jan, M.S. Recreational benefits of ecosystem services on and around artificial reefs: A case study in Penghu, Taiwan. Ocean Coast. Manag. 2013, 85, 58-64. [CrossRef]

25. Daneri, G.; Dellarossa, V.; Quiñones, R.; Jacob, B.; Montero, P.; Ulloa, O. Primary production and community respiration in the Humboldt Current System off Chile and associated oceanic areas. Mar. Ecol. Prog. Ser. 2000, 197, 41-49. [CrossRef]

26. Yuras, G.; Ulloa, O.; Hormazábal, S. On the annual cycle of coastal and open ocean satellite chlorophyll off Chile (18 $\left.{ }^{\circ} \mathrm{S}-40^{\circ} \mathrm{S}\right)$. Geophys. Res. Lett. 2005, 32, L23604. [CrossRef]

27. Lima, J.S.; Zalmon, I.R.; Love, M. Overview and trends of ecological and socioeconomic research on artificial reefs. Mar. Environ. Res. 2019, 145, 81-96. [CrossRef]

28. Baine, M. Artificial reefs: A review of their design, application, management and performance. Ocean Coast. Manag. 2001, 44, 241-259. [CrossRef]

29. Fabi, G.; Spagnolo, A.; Bellan-Santini, D.; Charbonnel, E.; Çiçek, B.A.; García, J.J.G.; Santos, M.N.D. Overview on artificial reefs in Europe. Braz. J. Oceanogr. 2011, 59, 155-166. [CrossRef]

30. Goldschmid, A.; Yip, M. An Overview of Artificial Reefs, Advantages and Disadvantages of Artificial Reefs Design, Material and Concepts of Realization around the Globe, Colloquial Meeting of Marine Biology I, Salzburg. 1998. Available online: http://www.sbg.ac.at/ipk/avstudio/pierofun/ar/reef.htm (accessed on 13 March 2017). 
31. Friend, M.; Cummins, H. The Impact of Artificial Reefs on the Marine Ecosystem. 2009. Available online: http://jrscience.wcp.muohio.edu/fieldcourses09/PapersMarineEcologyArticles/TheImpactofArtificialReef.html (accessed on 13 March 2017).

32. Yozzo, D.; Wilber, P.; Will, R.J. Beneficial use of dredged material for habitat creation, enhancement, and restoration in New York-New Jersey Harbor. J. Environ. Manag. 2004, 73, 39-52. [CrossRef]

33. De Pesca, S. Ministerio de Economía, Fomento y Reconstrucción, Servicio Nacional de Pesca, Ley de pesca y Acuicultura N 20.657, Chile. 1991. Available online: http://www.sernapesca.cl/index.php?option=com_ remository\&Itemid $=246 \&$ func $=$ fileinfo\&id $=42$ (accessed on 13 March 2017).

34. Estadístico, A. Censo 2002 Resultados (Volume 1); Instituto Nacional de Estadísticas-INE: Chile, 2002; Available online: www.ine.cl (accessed on 5 February 2017).

35. IBM Corp. IBM SPSS Statistics for Windows, Version 22.0; IBM Corp: Armonk, NY, USA, 2013.

36. CEPAL. Estadísticas Económicas de América Latina y el Caribe: Aspectos Metodológicos y Resultados del Cambio de año Base de 2005 a 2010; Cuadernos Estadísticos de la CEPAL: Santiageo, Chile, 2016; p. 43.

37. Stotz, W.; Caillaux, L.; Valdevenito, M.; Lancellotti, D.; Aburto, J.; Morales, J.; Guajardo, P.; Cerda, C. Criterios de Explotación de Recursos Bentónicos Secundarios en Áreas de manejo; Informe final proyecto FIP 2005-42; Fondo de Investigación Pesquera y de Acuicultura: Valparaíso, Chile, 2007; p. 424.

38. Merino, C.; Pizarro, P. Generación de arrecifes artificiales para el incremento de la producción y biodiversidad en el área de manejo de Pisagua, y la creación de servicios turisticos de inetereses especiales; Informe Proyecto FIC BIP N ${ }^{\circ}$ 30116701-0; Fondo de innovación para la competitividad, Región de Tarapacá: Tarapacá, Chile, 2015; p. 15.

39. Sernapesca. Sernapesca Anuarios Estadísticos, 2003-2016; Servicio Nacional de Pesca y Acuicultura: Valparaiso, Chile, 2017.

40. Fabi, G.; Scarcella, G.; Spagnolo, A.; Bortone, S.A.; Charbonnel, E.; Goutayer, J.J.; Trommelen, M. Practical guidelines for the use of artificial reefs in the Mediterranean and the Black Sea. General Fisheries Commission for the Mediterranean. Stud. Rev. 2015, 96, 1-74.

41. Castillo Rojas, R.; Tejada, A.; González Vargas, A.; Pastor Cuba, R.; Lucero Pérez, S. Comunidad bentónica del chanque Concholepas concholepas en el litoral de Tacna, Perú. Inf. Inst. Mar. Peru. 2012, 39, 114-121.

42. Pickering, H.; Whitmarsh, D. Artificial reefs and fisheries exploitation: A review of the 'attraction versus production's debate, the influence of design and its significance for policy. Fish. Res. 1997, 31, 39-59. [CrossRef]

43. De Pesca, S. Permisos para acuicultura tradicional y experimental en Área de Manejo y Explotación de Recursos Bentónicos (AMERB). 2016. Available online: http://www.subpesca.cl/portal/619/w3-article-92886.html. (accessed on 13 March 2017).

44. Gallardo, V.A. Large benthic microbial communities in sulphide biota under Peru-Chile subsurface countercurrent. Nature 1977, 268, 331-332. [CrossRef]

45. Gallardo, V.A.; Espinoza, C. New communities of large filamentous sulfur bacteria in the eastern South Pacific. Int. Microbiol. 2007, 10, 97-102. [CrossRef] [PubMed]

46. Gallardo, V.A.; Espinoza, C. Large multicellular filamentous bacteria under the oxygen minimum zone of the eastern South Pacific. In A Forgotten Biosphere; Hoover, R.B., Levin, G.V., Rozanov, A.Y., Davies, P.C.W., Eds.; SPIE: San Diego, CA, USA, 2007; p. 6694. [CrossRef]

47. Gallardo, V.A.; Fonseca, A.; Musleh, S.S.; Espinoza, C. Extrapolations of standing-stocks of big bacteria in Humboldt eastern boundary current ecosystem (HEBCE). Oceanography 2013, 1, 1000110. [CrossRef]

48. De Laire, F. Está Chile o no por la sustentabilidad de la pesca artesanal? Algunas reflexiones teóricas a partir del análisis de la situación de la Primera Región. Perspect. Perspect. Política Econ. Gest. 2002, 6, 141-158.

49. Peláez, G.C. Una mirada a los estudios pesqueros desde las ciencias sociales. Rev. Mex. Cienc. Agríc. 2015, 2, 357-365.

(C) 2020 by the authors. Licensee MDPI, Basel, Switzerland. This article is an open access article distributed under the terms and conditions of the Creative Commons Attribution (CC BY) license (http://creativecommons.org/licenses/by/4.0/). 